\title{
Effects of the current financial and economic crisis on the rural landscape as well as the agri-food sector in Europe and Central Asia
}

\author{
Csaba Csáki \\ Professor Emeritus, Department of Agricultural Economics and Rural Development, Corvinus \\ University of Budapest \\ E-mail: csaba.csaki@,uni-corvinus.hu
}

\section{Gertrud Buchenrieder}

Associated researcher, Leibniz Institute of Agricultural Development in Central and Eastern Europe

E-mail: buchenrieder@iamo.de

This paper reviews the expected effects of the current financial crisis and subsequent recession on the rural landscape, in particular the agri-food sector in Europe and Central Asia (ECA) on the basis of the structure of the rural economy and of different organisations and institutions. Empirical evidence suggests that the crisis has hit the ECA region the hardest. Agriculture contributes about $9 \%$ to gross domestic product (GDP) for the ECA region as a whole with $16 \%$ of the population being employed in the agricultural sector. As far as the impact of the financial crisis on the agri-food sector is concerned, there are a few interconnected issues: (1) reduction in income elastic food demand and commodity price decline, (2) loss of employment and earnings of rural people working in urban centres, implying also costly labour reallocation, (3) rising rural poverty originating mainly from lack of opportunities in the non-farm sector and a sizable decline of international remittances, (4) tightening of agricultural credit markets, and the (5) collapse of sectoral government support programs and social safety-net measures in many countries. The paper reveals how the crisis hit farming and broader agri-business differently in general and in the ECA sub-regions.

Keywords: financial crisis, ECA, agri-food sector

JEL-codes: 


\section{Introduction}

The global financial crisis, brewing for a while, really started to show its effects in the middle of 2007 and into 2008. It originated from countries with highly sophisticated financial markets. On September 15, 2008, the internationally renowned Lehman Brothers went bankrupt and kick-started a global economic crisis. ${ }^{1}$ Subsequently, the spectre of recession has affected even countries with financial markets not dealing with structured financial products $^{2}$ that had become popular as means of securitization. ${ }^{3}$ The financial crisis emerged to a large extent from a severe loss of value of such structured financial products, namely collateralized debt obligations (CDOs) of the American subprime housing credit market.

The transmission channels of the financial crisis are extremely diverse. The channels of effect include higher loan interest rates resulting in rationing or even a credit crunch, changes in capital flows and commodity prices, reductions in investment and trade as well as in employment or migration-cum-remittances (Blanchard 2009). The effects of the financial crisis and its aftermath (i.e. the economic crisis) combined with a substantial fiscal crisis in some countries ${ }^{4}$ have been harsh on many people, not the least on rural people. Rural people have been particularly suffering from the crisis due to sharp changes in (agricultural) commodity prices, even stronger rationing of the agricultural credit market, reduced wage rates (particularly for unskilled labour) due to loss of employment, either rural regional employment or international migratory employment.

This contribution concentrates on the effects of the current financial crisis and subsequent recession on the rural landscape, in particular the agri-food sector in the Commonwealth of Independent States (CIS) and the two major sub-regions of Central and Eastern Europe (CEE), namely the new EU member countries as well as the rest of the region: the Balkan

\footnotetext{
${ }^{1}$ One year after the collapse of Lehman Brothers, more and more leading policy makers in the financial market, among them also Ben Bernanke, the chief of the US Federal Reserve, voiced their opinion that the recession is technically over. Nevertheless, the economic situation, especially employment will continue to be weak for some more.

${ }^{2}$ A structured financial product is generally based on derivatives. A derivative is a financial instrument that is derived from some other asset, for instance real estate mortgages

${ }^{3}$ Securitization offered the promise of a new golden age of risk management by eliminating the mismatch between the long-term assets and short-term liabilities of traditional banks that had been the cause of innumerable financial crises since the dawn of banking. Through securitization, borrowers seeking long term liabilities could be matched with lenders seeking long term assets. Nevertheless, with regard to the subprime crisis, securitization also meant that banks pooled their various loans into sellable assets, thus off-loading risky loans onto others. Somehow it is ironic that a financial instrument designed to reduce risk and help lend more securities - would backfire so much.

${ }^{4}$ Public expenditures in real terms increased by more than $110 \%$ in Latvia over the period between 1998 and 2008, compared with an increase of slightly less than 40\% in the Czech Republic (World Bank 2010).
} 
countries. These regions are addressed in the following as Europe and Central Asia (ECA). As of today, the majority of the world's poor live in rural regions and rely on agriculture for a living - rural households make up $43 \%$ of the population in the ECA region and they are significantly poorer than their urban counterparts. Furthermore, agriculture contributes about $9 \%$ to gross domestic product (GDP) for the ECA region as a whole with $16 \%$ of the population is being employed in the agricultural sector (World Bank 2000).

\section{Causes and Macroeconomic Impacts of the Crisis}

How could this happen? No one thought that the financial system could collapse. It was assumed that sufficient safeguards were in place. Prosperity and stability were evidence that the system worked. Inflation was low, growth was high, and both appeared stable (Cecchetti 2009). So the crisis followed a long period of the 'Goldilocks' economy with over-optimistic expectations.

\subsection{Final Trigger of the Financial Crisis}

In its early stages, the financial crisis manifested itself as an acute liquidity shortage among financial intermediaries. In this phase, concerns over the solvency of the sophisticated centres of modern finance were increasing but a systemic collapse was deemed unlikely (EC 2009). After one year of bold efforts by policymakers, ${ }^{5}$ the financial crisis intensified in midSeptember 2008 to the point where it overwhelmed the real economy. The bankruptcy of Lehman Brothers on September 15, 2008 triggered a run in the interbank lending market, a dramatic spike in corporate bond rates, and a global loss of business and consumer confidence (Cecchetti 2009).

But the crisis did not begin or end there. Deregulation of the financial sector in the advanced countries has started in the early 1980s and resulted in various complicated and widely used financial innovations (particularly the emergence of securitized lending) that attempted to reduce individual investors' risks but in hindsight increased systemic risks (Lin - Martin 2009). Unfortunately, weaknesses in financial regulation interacted with financial innovations such as securitized lending to create serious financial system vulnerabilities. The banking sector assumed that US housing prices would continue to rise and thus quickly raise the value

\footnotetext{
${ }^{5}$ Central banks had been supplying short-term funding to smooth needed adjustments in the banking sector, but that alone could not stem bank losses. So what had been addressed as a liquidity crisis was confirmed to be a solvency crisis.
} 
of the houses against which the loans were secured. This resulted in very high ratios of loan to value at the time when the loan contract was signed. Moreover, the possibility of assumingly risk-free securitization resulted in low ratios of capital ${ }^{6}$ held by many banks.

From 2006 onwards, the housing prices in the US turned downwards. Banks reacted by increasing their interest rates. Many home-owners whose equity had become negative and now faced rising interest rates defaulted on their loans. This behaviour was conveyed by the non-recourse nature of the US mortgage loans. The financial sector's situation deteriorated further because many banks cut back on lending and sold assets - frequently at fire-sale prices - in order to preserve their capital (Blanchard 2009; Lin - Martin 2009). The now nearly worthless derivatives, consisting to a large extent of CDO's of the failing American subprime mortgage market, got the financial crisis finally going, although other factors were contributing to it as well. ${ }^{7}$

Early on, many thought that the ECA region was sufficiently decoupled from the sophisticated Western financial systems. ECA has not had a subprime mortgage crisis, for instance. On the one hand, many countries in the ECA region had witnessed rapid growth and wealth creation in recent years. On the other hand, most countries were in the state of a difficult fiscal situation with large budget deficits. These budget deficits had been financed by the international financial market but had become unsustainable under the changed financial climate. As a result, the governments in the ECA region - other than the EU-15 or the US faced limited possibilities to launch rescue packages for the banking sector and stimulating packages for the economy.

Thus, the crisis has shown that in an increasingly inter-connected world, there are always knock-on effects. Countries, which are the home base of cross-border banking activities, for instance in emerging economies in CEE are strongly affected despite their abstinence from the securitization market (EC 2009). The macroeconomic imbalances in some countries, which were often fiscal in nature (especially in Hungary) aggravated the situation (World Bank

\footnotetext{
${ }^{6}$ Subsequently, many financial market experts called for a higher equity capital ratio for banks. This ratio lies presently at $4 \%$, the recommended level is $8 \%$.Nevertheless, for the future, figures between $10-20 \%$ are discussed. The recommendations from the G20 (Group of 20 Finance Ministers and Central Bank Governors) Summit in Pittsburgh, 24-25 September 2009 go towards this direction. Nevertheless, international rules should be implemented by 2012 to avoid negative effects on the credit supply. The changes in the Capital Requirements Directive of the EU are for the time being unaffected by the G20 recommendations.

${ }^{7}$ For a more comprehensive overview see for instance Blanchard (2009), Orlowski (2009) and Lin and Martin (2009).
} 
2010). The ongoing recession is thus likely to leave deep and long-lasting traces on economic performance and entail social hardship of many kinds.

\subsection{Summary of the Major Macroeconomic Effects of Crisis}

The financial crisis had manifold effects on the real sector. The following major effects are briefly discussed: (1) credit crunch, (2) global trade collapse, (3) capital outflows, (4) job cuts and pressure on real wage rates, and (5) effects on social safety nets.

Banks play a critical role in the real sector, as 'money (credit) makes the economy go round'. In a global economy, when banks cut back on lending, most severely a credit runch $^{8}$ can ripple through the entire (real) economy very quickly turning a global financial crisis into a global economic crisis. Initially, the losses mostly originated in the US, the write-downs of banks are estimated however to be considerably larger in Europe, notably in the UK and the euro area. Moreover, in the process of deleveraging, banks drastically reduced their exposure to emerging markets, closing credit lines and repatriating capital. Hence the crisis snowballed further by restraining funding in countries (especially the emerging European economics and the CIS region) whose financial system had been little affected initially (EC 2009). ECA is by far the region most dependent on debt financing and the most exposed to the current liquidity crunch (Montes-Negret 2009). As it was mentioned, a region specific phenomenon is fiscal crisis; the resulting budget deficit had been financed on the international financial market. The restrained funding exaggerated negative impacts, which otherwise would be more manageable. According to the IMF (2009) the supply of bank credit remains narrow in 2009 and has continued to be so into 2010 both in the United States and Europe. ${ }^{9}$

As lending standards stiffened and in the wake of drops in asset prices (financial and reality), savings increased and demand for consumer durables (notably cars) and residential investments plummeted. This was amplified by the inventory cycle, with involuntary stock building prompting further production cuts in manufacturing, also reducing demand for investment goods (EC 2009; McKibbin - Stoeckel 2009). Consequently, in the final quarter of

\footnotetext{
${ }^{8}$ An entire banking system that lacks confidence in lending (due to the failure in the derivative instruments) as it faces massive losses will try to shore up reserves and may reduce access to credit, or make it more difficult and expensive to obtain credit even for creditworthy borrowers, in other words ration credit. If this applies to the whole economy, one talks about a credit crunch.

${ }^{9}$ Nevertheless, the three major international financial institutions, the European Bank for Reconstruction and Development (EBRD), the European Investment Bank (EIB) Group, and the World Bank Group pledged on February 27, 2009, to support banking sector stability and lending to the real economy in crisis-hit CEE with a financing plan of up to $€ 24.5$ billion for 2009-2010.
} 
2008, imports as well as exports have both declined, ${ }^{10}$ or in other words, global trade collapsed. Why has the collapse in trade been so severe? The trade squeeze was deeper than originally expected for several reasons. Generally, the composition of the demand is responsible for the trade shock: business investments and demand for consumer durables are strongly credit dependent and trade intensive (EC 2009). Furthermore, elasticity of real world trade to real world income (GDP) has increased over time from under 2 to over $3.5 .^{11}$ In addition, trade responds more sharply to GDP during global slowdowns ${ }^{12}$ than during tranquil times. The 2010 July estimate of the World Bank is that real world GDP growth decelerated by 4.7 percentage points in 2009. Based on this estimate and an elasticity of trade to income during the downturn of between 3.5 and 5, Freund (2009) estimates a deceleration in real trade growth of between 16-24 percentage points in 2009 .

The results were quickly felt in emerging and developing economies, not only through the sharp drop in trade volumes and the increased difficulties to obtain financing to counteract the macroeconomic (fiscal) imbalances but also large capital outflows. ${ }^{13}$ Even prior to the crisis, capital outflow was severe. In the heavily indebted countries of the ECA region, capital outflow as compared to capital inflow from foreign loans was 80 cents on every dollar (Schmognerova 2005). Among transition countries, majority foreign-owned banking sectors are generally found in the new member states of the European Union, accession and candidate countries, and the countries in the Western Balkans that have Stabilization and Association agreements with the EU (World Bank 2010).

Since the crisis began, a large repatriation of funds to the headquarters of foreign banks is observed as well as a drastic reduction of inter-bank credit lines from international banks to

\footnotetext{
${ }^{10}$ Demand for investment goods is more volatile than consumer durables. The loss in business confidence reduced investment demand. Economic theory suggests that this would result in a collapse of imports and due to currency devaluation, a substantial increase in exports. This was certainly the response of the Asian economies to the Asian crisis in 1997-1999 (McKibbin - Martin 1999). In the current financial crisis, imports and exports declined alike. A likely explanation for this phenomenon is that the crisis is truly worldwide (Lin - Martin 2009).

${ }^{11}$ The significant increase in the elasticity of trade to income may be mainly attributed to the fragmentation of production.

${ }_{12}$ Trade responds to income during times of economic crisis because (1) firms draw down accumulated inventories, (2) protectionist policies may kick in, (3) goods make up the bulk of trade and goods decline more sharply than services, but services make up the bulk of GDP, (4) trade is measured in gross value and GDP in value added, and (5) more goods may be sourced from home country suppliers because of trust of financing problems (Freund 2009).

${ }^{13}$ Large capital outflows, or in other words capital flight is part of the outflow of resident capital which is motivated by economic and political uncertainty (Kindleberger 1937). This definition stresses the point that outflows of capital can take place even if they are not motivated by flight factors (Schneider 2003).
} 
domestic banks (Montes-Negret 2009). The Eastern European countries of the EU and the Balkans is particularly exposed to Swedish and Austrian banks - Swedish banks accounting for $51-85 \%$ of the banking sector of Baltic countries and Austrian banks for $48 \%$ (see Figure 1). In Albania, for instance the Raiffeissen bank accounts for $45 \%$ and in Croatia, Unicredit for $23 \%$ of the banking sector. The high profitability of ECA subsidiary banks may have led parent banks in the beginning of the crisis to protect their franchise value, but ultimately, the global credit crunch may force them to contract their funding to them (Montes-Negret 2009). Nevertheless, the European Banking Coordination Initiative (the Vienna initiative) has attempted to ensure that Western European parent banks maintain their exposure to ECA countries and adequately capitalize their banks (World Bank 2010).

Figure 1. Share of Swedish and Austrian banks in loan portfolios (2005)

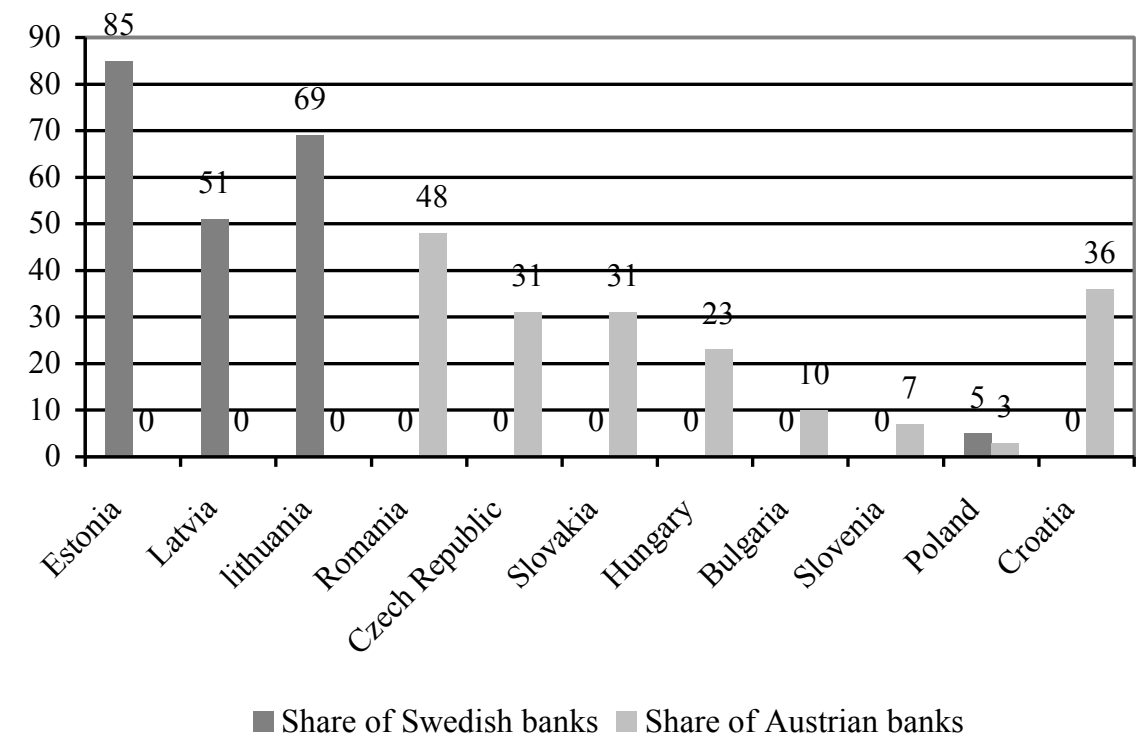

Source: Montes-Negret (2009)

For instance, the crisis has halted the Russian economic boom. In 2008 and 2009, capital outflow exceeded inflow (Sandschneider 2008). During the six months prior to February 2009, the Central Bank of Russia sold 210 billion USD in international reserves $-60 \%$ being capital outflows (Korolev 2009). Generally, all those ECA countries that had experienced strong foreign direct investment (FDI) inflows due to their export of natural resources such as metal, petrol or gas, of which the prices are starting to bottom out, experience a huge demand for financing. 
A consequence of the economic crisis has been downward pressure on demand for labour, leading to job cuts and pressure on real wage rates. The socioeconomic groups with relatively loose work contracts (i.e. temporary contracts and self-employed) and the low and medium skilled workers have born much of the brunt of the recession so far. Especially in the EU-15, increased internal flexibility (flexible working time arrangements, short-time working schemes, temporary plant closures etc.), part-time unemployment compensation schemes, coupled with nominal wage concessions in return for employment stability in some firms/industries may have prevented, though perhaps only delayed, more significant labour shedding so far (with short-time working and temporary closures in the car industry as the most prominent example) (EC 2009). Preliminary information suggests that registered unemployment more than doubled in the Baltic States while it increased by about $60 \%$ in Turkey and between 20 and 40\% in the Czech and Slovak Republics, Romania, the Russian Federation, Slovenia, and Ukraine. Even recognizing that incentives to register depend inter alia on the generosity of benefits to be received, the data suggest that unemployment may be on the rise in many ECA countries. In the Russian Federation, the numbers in poverty as a proportion of the population (using a national poverty line based on an officially defined subsistence level) increased by almost one-third between the last quarter of 2008 and the first quarter of 2009, implying 6 million more people in poverty (World Bank 2010).

By way of summary, the credit crunch, the sharp contraction in domestic and external demand, the macroeconomic (fiscal) imbalances, and the reversal of capital flows due to heightened investor risk aversion have led to the contraction in the real sectors and rising unemployment. The year 2009 will be remembered in ECA as the year when the economic crisis - or as the global crisis hit the region the hardest (see Table 1). The Baltic countries experience the largest income contraction, ranging from -10 to $-12 \%$. The economic contraction in Russia is having adverse effects on many Central Asian and South-eastern European (SEE) countries, whose economies are closely linked to Russia through trade relations or migrant works (Ersado and Umali-Deininger 2009). The average GDP contraction in the European Union (EU) in 2009 was $-4.0 \%$ - the contraction in the Baltic States and Hungary was even higher. Table 1 also shows that the general government balance, which is an indicator of lacking fiscal revenues and/or governmental overspending, deteriorated in many countries. Due to the overall support of government finances in Europe in 2009 and 2010, the government balance deteriorated by 5 percentage points in the EU and around 4.5 percentage points in the euro area (EC 2009, Eurostat 2009). 
Table 1: GDP growth and government balance in the ECA region and the EU

\begin{tabular}{|c|c|c|c|c|c|c|c|c|}
\hline \multirow[b]{3}{*}{ Country } & \multicolumn{4}{|c|}{$\begin{array}{l}\text { GDP at constant prices, } \\
\text { annual change in } \%\end{array}$} & \multicolumn{4}{|c|}{$\begin{array}{c}\text { General government balance, } \\
\text { as \% of GDP }\end{array}$} \\
\hline & \multirow{2}{*}{2007} & \multirow{2}{*}{2008} & \multicolumn{2}{|c|}{ Estimate } & \multirow{2}{*}{2007} & \multirow{2}{*}{2008} & \multicolumn{2}{|c|}{ Estimate } \\
\hline & & & 2009 & 2010 & & & 2009 & 2010 \\
\hline \multicolumn{9}{|c|}{ Higher-income CIS } \\
\hline Russia & 8.1 & 5.6 & -7.5 & 1.5 & 3.2 & 3.8 & -7.7 & -5.8 \\
\hline Ukraine & 7.9 & 2.1 & -14.0 & 2.7 & -1.1 & -1.5 & -8.0 & -4.0 \\
\hline Kazakhstan & 8.9 & 3.2 & -2.0 & 2.0 & -1.7 & -2.1 & -3.4 & -2.7 \\
\hline Belarus & 8.6 & 10.0 & -1.2 & 1.8 & 0.4 & -1.4 & -2.0 & -2.5 \\
\hline Turkmenistan & 11.6 & 10.5 & 4.0 & 15.3 & 4.0 & 3.2 & -2.0 & 1.0 \\
\hline Azerbaijan & 23.4 & 11.6 & 7.5 & 7.4 & -6.2 & -6.4 & -7.0 & -5.3 \\
\hline \multicolumn{9}{|l|}{ Low-income CIS } \\
\hline Armenia & 13.7 & 6.8 & -15.6 & 1.2 & 0.1 & -1.2 & -5.7 & -5.6 \\
\hline Georgia & 12.3 & 2.1 & -4.0 & 2.0 & -4.7 & -6.3 & -8.8 & -6.5 \\
\hline Kyrgyz Republic & 8.5 & 7.6 & 1.5 & 3.0 & 0.0 & 0.8 & -0.6 & -0.3 \\
\hline Moldova & 3.0 & 7.2 & -9.0 & 0.0 & -0.3 & -1.0 & -7.0 & -3.5 \\
\hline Tajikistan & 7.8 & 7.9 & 2.0 & 3.0 & 1.1 & 1.9 & -1.9 & -2.0 \\
\hline Uzbekistan & 9.5 & 9.0 & 7.0 & 7.0 & & & & \\
\hline \multicolumn{9}{|l|}{ Emerging Europe } \\
\hline Turkey & 4.7 & 0.9 & -6.5 & 3.7 & -1.6 & -1.8 & -6.3 & -5.9 \\
\hline \multicolumn{9}{|l|}{ Baltics } \\
\hline - Estonia & 7.2 & -3.6 & -14.0 & -2.6 & 2.6 & -2.7 & -4.0 & -3.0 \\
\hline - Latvia & 10.0 & -4.6 & -18.0 & -4.0 & -0.3 & -4.1 & -9.8 & -8.9 \\
\hline - Lithuania & 8.9 & 3.0 & -18.5 & -4.0 & -1.0 & -3.2 & -9.0 & -6.8 \\
\hline \multicolumn{9}{|l|}{ Central Europe } \\
\hline Hungary & 1.2 & 0.6 & -6.7 & -0.9 & -5.0 & -3.8 & -4.0 & -3.9 \\
\hline Poland & 6.8 & 4.9 & 1.0 & 2.2 & -1.9 & -3.6 & -5.8 & -6.5 \\
\hline Slovenia & 6.8 & 3.5 & -4.7 & 0.6 & 0.3 & -0.3 & -5.9 & -5.3 \\
\hline \multicolumn{9}{|c|}{ Southern Eastern Europe } \\
\hline Bulgaria & 6.2 & 6.0 & -6.5 & -2.5 & 0.1 & 1.8 & -1.3 & 0.3 \\
\hline Croatia & 5.5 & 2.4 & -5.2 & 0.4 & -2.6 & -2.1 & -3.8 & -2.8 \\
\hline Romania & 6.2 & 7.1 & -8.5 & 0.5 & -2.5 & -5.5 & -7.5 & -6.3 \\
\hline Slovak Republic & 10.4 & 6.4 & -4.7 & 3.7 & -1.9 & -2.5 & -5.3 & -4.4 \\
\hline Czech Republic & 6.1 & 2.7 & -4.3 & 1.3 & -0.6 & -1.4 & -6.0 & -7.0 \\
\hline Euro zone & $\ldots$ & 0.8 & -4.0 & -0.1 & -0.6 & -2.0 & -7.0 & -7.0 \\
\hline European Union & $\ldots$ & 0.9 & -4.0 & -01 & -0.8 & -2.3 & -6.8 & -6.8 \\
\hline
\end{tabular}

Notes: The general government balance is defined as the balance between the revenues and expenditures of the general government sector. The indicator is one of the Maastricht convergence criteria according to which the general government deficit must not exceed $3 \%$ of GDP 
Sources: Ersado and Umali-Deininger (2009: 3) based on IMF (2009); EC (2009: 28, 64), Eurostat (2009), Datenbank EIU, Country Reports Archive of the Economist Intelligence Unit

Social safety nets will have to be strengthened to deal with the human dimension of the crisis. Most ECA countries-including, encouragingly, several low income and lower-middleincome countries - have at least one well-targeted program where a high proportion of benefits reaches the poorest quintile of households and that could be scaled up in response to the crisis. The generosity of means-tested safety nets is highly variable, ranging from modest in Albania, Bosnia, Kazakhstan and the Kyrgyz Republic to generous in Estonia, Georgia, and Kosovo. Preliminary data from a few countries show significant declines in the number of beneficiaries between June 2008 and June 2009 - when more households have become vulnerable. The situation bears close monitoring (World Bank 2010).

\section{Effects of the Crisis on the Rural Landscape and the Agri-food Sector in ECA}

The financial crisis had manifold effects on the real economic sector. The following effects are discussed in more detail for the agri-food sector in ECA: (1) changes in the farm commodity prices, (2) job cuts and pressure on real wage rates, (3) decrease in international and regional labour migration and remittances, (4) tightening in agricultural credit markets, (5) reductions in social programs, and (6) weakening in international aid.

The implications of the financial and economic crisis for the rural landscape and particularly the agri-food sector are still evolving. While the agri-food sector may cope with the crisis somehow, as it is less dependent on credit and demand is less sensitive to income falls, a larger impact on the rural economy will likely come from the loss of jobs in the non-farm sector, by reducing local and inter-regional non-farm employment and income for farm and other rural households. ${ }^{14}$ Therefore, it is advisable to examine the vulnerability of the people employed in the agri-food sector as well as the rural poor in general to different implications of the crisis. The World Bank estimates that in 2009 alone, the number of poor in the ECA region will rise by 15 million. The World Bank (2009) further states: the crisis has hit home (see Hiba! A hivatkozási forrás nem található.).

Figure 2. The crisis hits home - The transmission channels

\footnotetext{
${ }^{14}$ Heady et al. (2009) report that the agricultural sector generally suffers less than the non-farm sector during financial crises, and sometimes even experiences positive growth.
} 

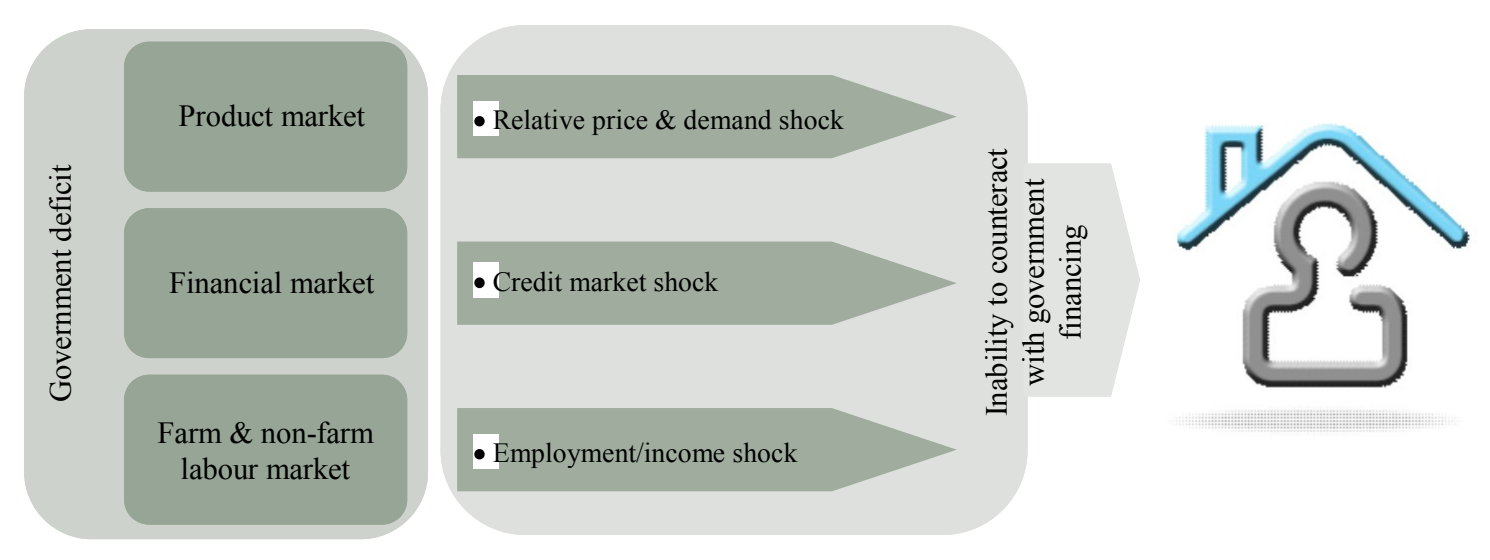

Source: World Bank (2009: 17)

While the general impact on the rural families can be delineated, the severity of individual transmission channels may vary among the ECA countries, especially since the structure of the farming and non-farm sector differs. Insofar, the crisis is visible across the region but has its own features in different country groups (and farming categories). There are at least five different country groups: (1) the new EU member countries, (2) oil and/or natural gas exporters such as Russia or Kazakhstan, (3) the rest of the CIS, (4) the Central Asian countries, and (5) the West Balkan. The new EU member countries are under the community umbrella and have some protection and support, making adjustment easier. The Common Agricultural Policy (CAP) provides continued and sizable subsidy flows to the farmers. Russia has entered the crisis with significant reserves and has a sizable scope for adjustment. The rest of the CIS including the Ukraine, Moldova, and the Caucasus are those most hardly hit by the crisis - similarly to the Central Asian Countries. The countries of the West Balkan also suffered significantly. As briefly mentioned above, the agri-food sector was impacted upon differently too. Impacts upon large farms are similar in many ways to the impact upon the industrial sector. Small farms, particularly subsistence farms however were impacted mainly indirectly by loss of employment in the non-farm sector.

Obviously, the effect of changing agricultural commodity prices on farmer incomes varies along different commodities. The financial crisis started at an historical peak of nominal commodity prices in 2008. ${ }^{15}$ This has led to record agricultural revenues in 2008. Nevertheless, the prices have proceeded unevenly depending on the demand impact (domestic

\footnotetext{
${ }^{15}$ In early 2008 civil unrest in several developing countries raised alarm about the impact of food price hikes on the poorest. However, during the summer of 2008 - two months before the depth of the financial crisis was revealed - most commodity prices started to fall. Nevertheless, average prices for the whole year of 2008 remained relatively high and were still above historical trend levels in real terms (OECD 2009).
} 
and foreign) (see Figure 3). In the core of the countries concerned, the decline of grain prices and lower milk prices made the largest impact. It must also be mentioned that the depreciation of currencies helped agricultural exports and improved the position of agro-processing in some countries, especially in those countries with a surplus of agricultural products. Declines in prices for staple foods typically have a positive effect on very poor rural people because they spend a large share of their incomes on staple foods. What many do not realize is that even farmers are often net buyers of staple foods (Ivanic - Martin 2008). This observation is true for developing countries but to some extent also for transition countries, especially as it concerns the small-scale farm households. Csáki (2009) estimates that there exist about 30 million small, predominately subsistence orientated farms $(0.5-1 \text { ha or less than } 1 \mathrm{ESU})^{16}$ in the former Soviet Union and CEE. Declines in the prices of some higher income-elasticity foods such as dairy products, beef or fruits and vegetables may, however, put pressure on the incomes of small-scale farms.

\section{Figure 3: Resilience of agriculture facing the crisis: illustrative agricultural examples}

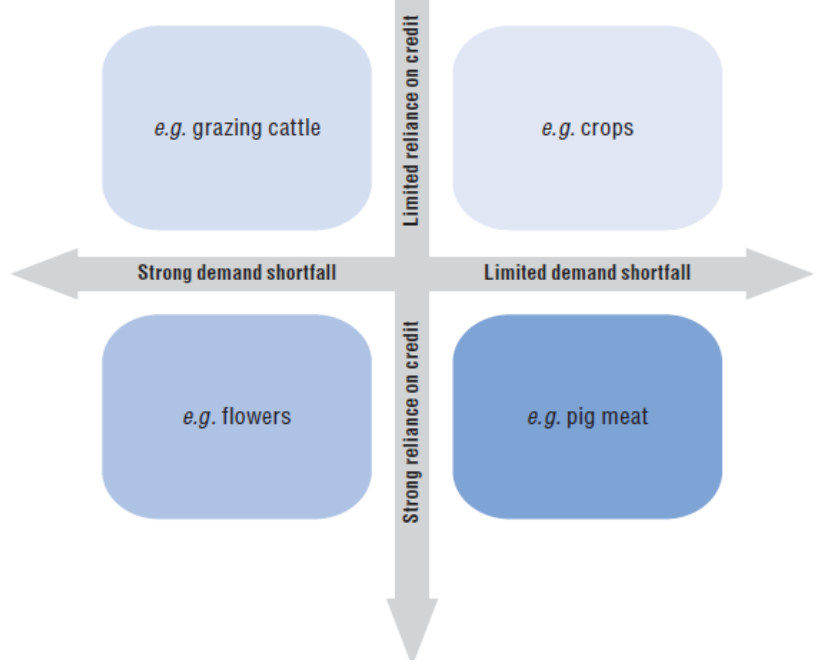

Source: OECD (2009: 28)

As indicated above, a major channel for transmission of the crisis is the loss of employment and earnings. Nevertheless, the crisis will have a heterogeneous impact on labour market outcomes across households. In fact it depends on (1) the sector of employment whereby farm

\footnotetext{
${ }^{16}$ The EU measures farm size in European Size Units (ESU). The value of 1 ESU is defined as a fixed number of EUR of Farm Gross Margin (FGM). Currently, one ESU equals 1,200 €. Based on this measure, more than $60 \%$ of the farms in the new EU member states in CEE are subsistence farms (smaller than 1 ESU).
} 
households have often diversified their employment, (2) the degree of the sector's exposure to external markets, and (3) on household characteristics such as demographics, educational attainments, and location.

As mentioned in the beginning, rural households in ECA often diversify their income sources. The income sources span from farm income, non-farm income in the region (self-employment and waged employment) or abroad (mainly unskilled waged employment) to unearned income (particularly social transfers). If there are inter-regional linkages, for instance in terms of rural-urban labour migration, job losses in non-rural sectors may induce a reversal in rural to urban migration and increase the pressure on the rural labour market and wage rates. In Armenia, for instance, the construction and export-oriented industries suffered most from the crisis. Insofar, the most prominent effect of the global economic crisis is the loss of jobs and pressure on wage rates (nationally and internationally) especially in the non-farm sector. This leads to cuts in the labour earnings or, in the extreme case to people slipping into poverty. In fact, the crisis has put at risk the gains in poverty reduction in the region. Poverty increased in ECA from $6.9 \%$ (2008) to $7.8 \%$ (2009) based on the international poverty line in US\$ PPP 2.5 per capita per day. More importantly, for nearly all ECA countries, poverty incidence is higher in rural than in urban areas, highlighting the ruralisation of poverty in the region (see Figure 4). For instance, only about $26 \%$ of the Russian population live in rural areas but almost $60 \%$ of the poor live there (Ersado - Umali-Deiniger 2009).

Figure 4. Ratio of rural to urban poverty rate, 2006 to 2007

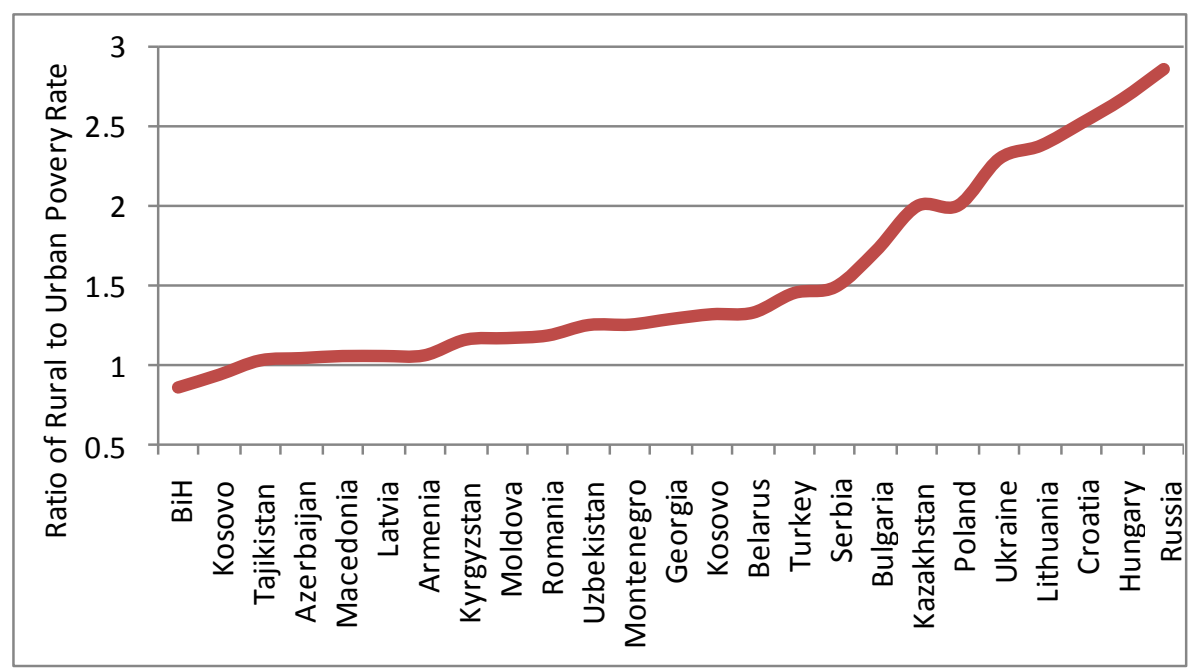

Source: Ersado and Umali-Deininger (2009: 6). 
Many countries in ECA are heavily dependent on remittances - remittances account for a large share of GDP. International labour migration (cum remittances) have slowed very rapidly in response to declines in demand for labour in key areas such as Russia and Poland (in the former Eastern Bloc) or in Italy, Germany and the UK, and to the tightening of immigration policies. Associated with this reduction in migration has been a reduction in remittance flows. Reductions in remittances have direct effects by reducing the purchasing power of the families in the countries of origin and indirect effects by lowering the demand for labour in non-traded sectors such as the construction of housing, an area heavily influenced by spending from remittances (Lin - Martin 2009). Ratha et al. (2009) estimated that global remittances fell by $7.3 \%$ on average in 2009 to 304 billion US\$ from 328 billion US\$ in 2008. Often, it is the rural population that is involved in outward migration because of hidden unemployment in the agricultural sector and a lack of alternative non-farm employment opportunities in rural regions.

Migrants from countries in ECA have been affected by the deepening recession and a rise in anti-immigration sentiment in Russia and the UK. ECA is expected to experience a very large percentage decline (-15\%) in migration in 2009 (Figure 5a). The impact of the worsening employment outlook in Russia has been particularly severe for Central Asian countries such as Tajikistan and the Kyrgyz Republic that receive a large share of remittances from Russia, and where remittances are a large share of GDP (see Figure 5b and Figure 6). Indeed, Russia is home to the second-largest number of migrants in the world after the United States. Most migrants in Russia are employed in the sectors worst affected by the crisis: construction and export-led manufacturing. Most migrant labourers to Russia tend to be relatively poorer and the bulk of them generally originate from the rural areas. They are temporary migrants and tend to go for short durations. When seasonal migrant workers lose their jobs and fail to find new seasonal jobs, unemployment (in rural areas) rises and remittance flows are severely reduced (Ersado - Umali-Deininger 2009). Combined with a deteriorating economic outlook for Russia, the sharp depreciation of the Russian ruble since September 2008 has reduced remittance inflows in nominal dollar terms to the Central Asian countries in 2009 (Ratha et al. 2009). The World Bank estimates that the economic slowdown and the drastic reductions in remittance flows lead to 2.1 to 5.3 percentage point increase in rural poverty in Armenia, Moldova, the Kyrgyz Republic and Tajikistan (Ersado - Umali-Deininger 2009). In Tajikistan, the poorest country in the region, it is estimated that a $30 \%$ decline in remittances would cut household consumption in the poorest quintile by around 20\% (World Bank 2010). 
$35 \%$ of remittances to the ECA region come from Western Europe (Figure 5b). Migration from CEE goes mainly to Western Europe. Particularly the eastern new member states of the EU such as Poland benefited from the opening of the EU labour market. The resulting increases in migration to the UK and Ireland more than doubled remittances between 2004 and 2008. With a decline in economic activity in the UK, many migrants have returned and remittance flows declined (Ratha et al. 2009).

\section{Figure 5. Remittance sources and flows}

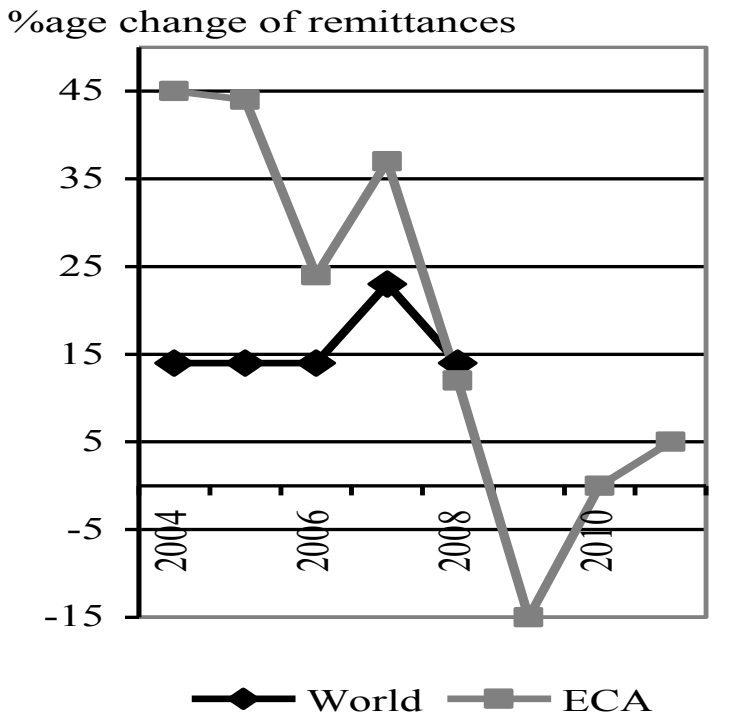

(a) Remittance flows to ECA expected to decline in 2009 but recover in 2010

Source: Ratha et al. (2009) and Ersado and UmaliDeininger (2009)

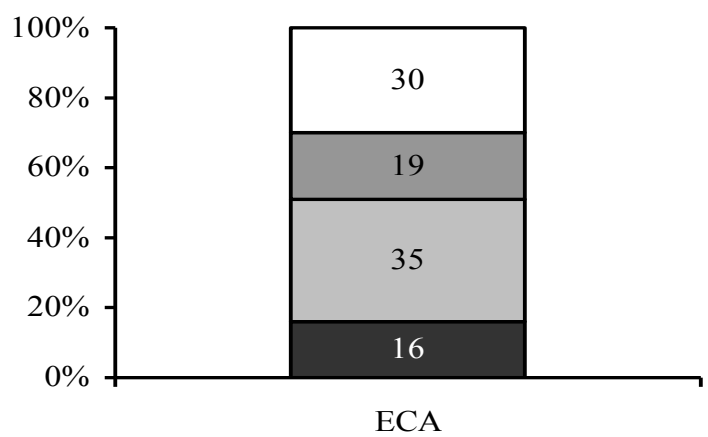

$\square$ CIS, mainly Russia

$\square$ Other high income countries

$\square$ Western Europe

$\square$ United States

\section{(b) Sources of remittances for ECA region,}

2008

Source: Ersado and Umali-Deininger (2009:

5)

The effect of job cuts on international migration and remittance flows to rural areas has received a great deal of attention. Nevertheless, there exists also a strong linkage between national rural-urban migration ${ }^{17}$ and rural household income. The crisis certainly indirectly impacts on rural household income through its impact on the urban labour market too (Ersado - Umali-Deininger 2009). Laying-off rural-urban migrants induces costly labour reallocation. This implies the need to find employment in other areas. Rural-urban migrants can move into

\footnotetext{
${ }^{17}$ Huang et al. (2009) reported that the reduction in demand for labour in the Chinese export sector or construction business have caused a sharp decline in the number of internal rural-urban migrants (about 34 million people were laid off) and their wage rate (ca. 830 Yuan in 2008, ca. 790 Yuan in 2009). About half of the people that were actually laid off have found a new non-farm job in 2009, albeit at a lower wage rate. Of those who were laid off and did not yet find a new job in the non-farm sector, most (two-thirds) returned back to farming.
} 
the non-traded sectors, either in urban or rural regions (the outlook of rural regions is clouded by the reductions in remittance flows) or in the agricultural (subsistence) sector (Ersado Umali-Deininger 2009, Lin - Martin 2009). Experience with past economic crises showed clear evidence of urban to rural migration. This in turn can induce a fall in wages for farm workers, which only benefits those farm households that are net hirers of labour (Bresciani et al. 2002). Ersado and Umali-Deininger (2009) simulated for instance the impact of the crisis on rural poverty in Armenia taking into account sectoral patterns of growth and employment. They estimated a 3.1 percentage points increase (from $23.5 \%$ of the rural population in 2008 to $26.5 \%$ in 2010 ) in rural poverty between 2008 and 2010 through the labour market transmission channel alone.

Figure 6. Top recipients of migrant remittances among ECA countries in 2007, \% of GDP

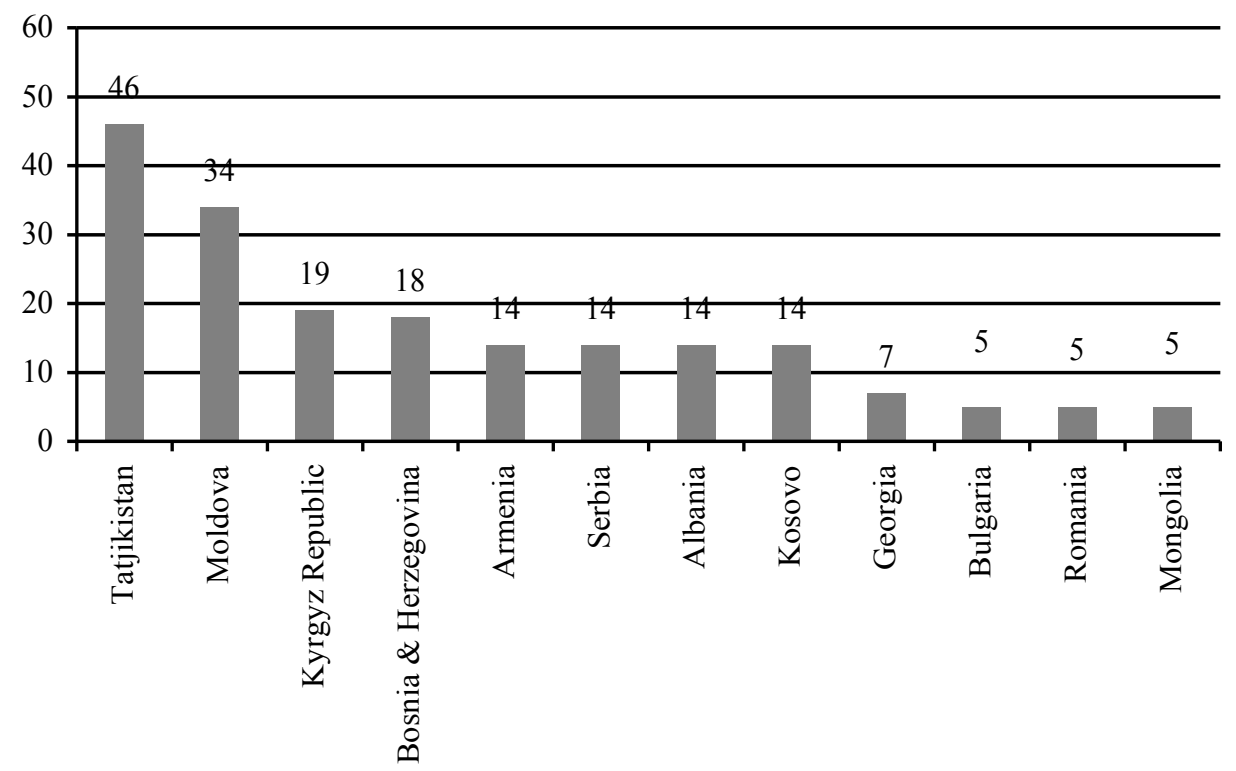

Source: Ratha et al. (2009) and Ersado - Umali-Deininger (2009)

In general, remittance flows are stable or countercyclical during an economic downturn in the recipient country and resilient in the face of an economic slowdown in the source economy. The current financial crisis has hit every country at once and it seems that remittances cannot function as an income stabilising livelihood strategy (Ersado - Umali-Deininger 2009).

Estimating the increases in production and trade costs associated with the tightening of agricultural lending is difficult, particularly since the rise in the effective cost of capital associated with credit rationing are unobservable. Nevertheless, credit scarcity is likely to 
diminish loan volumes in the agri-food sector too. However, the OECD (2009) claims that the financial crisis may not have significantly affected agricultural credit in $2008 .{ }^{18}$ By early 2009, however, a reverse in loan trends had been reported by some banks. It seems clear that the direct impacts on production costs in the agri-food sector, when dominated by small-scale farms, are relatively small. Nevertheless, larger scale farms in ECA with a higher volume of credit-financed working capital may be more constrained due to the crisis. It is no secret that the agri-food sector never was and probably never will be the preferred customer of the banking sector. Credit rationing to the agri-food sector has been always present - the financial crisis may make it only more visible (see Box 1). This is not to say that countries may not try to support the agricultural credit market. Poland for instance, decreased interest rates from 3.5 to $2 \%$ for preferential credits and extended reimbursement periods for credit to agriculture by 2-3 years. Some emerging countries also announced action plans for agriculture. At the beginning of 2009, Russia adopted a series of measures to facilitate the in-flow of finance to agriculture, it (EC 2009: 61f):

- $\quad$ allocated budgetary funds for capitalising the two largest banks lending to agriculture,

- $\quad$ increased funds for subsidising interest rates on agricultural loans,

- $\quad$ extended repayment periods for certain types of subsidised loans, and

- $\quad$ extended government guarantees of loans for agricultural enterprises that are included in the list of key national enterprises.

\section{Box 1: Bulgarian farms caught between financial and commodity market pressure}

Now, after the election of the Bulgarian new parliament, the stage is open for the economic crisis to show its full impact. Most agricultural commodity prices are currently in a trough, the pressure of competition due to imports becomes more and more apparent, and non-farm income dwindles because of rising unemployment. Still the new Bulgarian government and the unfreezing of EU-funds give some hope. Nevertheless, recovery from the crises will require patience.

The banking sector can be considered still relatively stable. Agricultural finance as an outpost of the Bulgarian banking sector is especially hit by the cold wind. After actively promoting micro-loans in rural areas, most banks now withdraw from this market segment and concentrate on cleaning up their portfolios. Paper is used double-sided, traveling expenses are reduced, and loan policies became more prudent. As the share of restructured and bad loans increases, banks and other financial intermediaries are busy with monitoring their borrowers. The appearance of loan officers in villages signals repayment problems. This creates rumors, strains the image of banks, and reawakes memories of the 1997 banking crisis among the villagers.

Florian Amersdorffer (Field work observations, 2009)

\footnotetext{
${ }^{18}$ For instance, the National Bank of Poland reports that credit to agriculture as index $(\mathrm{Q} 4-2006=100)$ was 119 in Q4-2007 and 157 in Q4-2008 (OECD 2009).
} 
Because the general government balances ${ }^{19}$ are under extreme pressure as a consequence of the crisis, there are also concerns that governments could reduce their social transfers. As social transfers in transition countries are on average substantially lower than in Western countries, this may impact heavily on vulnerable population groups. For instance in the new member states of the 2004 EU enlargement round, expenditures on social protection are ten percentage points less in terms of GDP than the EU-15 average of around 27\% (EC 2006). In the case of the EU-25, the majority of social protection spending goes into pensions. This is not to say, that there do not exist specific programs targeting the poor and vulnerable. One of the major effects of the crisis is that these social programs are threatened by the fiscal crises in many countries. Budget cuts impact by reducing social programs vitally important for rural people and especially for minority groups present in many ECA countries, for instance the Romas. Ersado and Umali-Deininger (2009) point out Albania, Armenia, Kyrgyzstan, Georgia, and Azerbaijan as countries with effective safety nets that focus on poor families. But there is also considerable room for improvement in many countries, for instance Moldova, Bosnia, Tajikistan and Russia. Their social safety net programs appear to be weakly implemented and inadequately targeted although they spend between 1-5\% of GDP on them.

Not only foreign direct capital (notably foreign direct investment) but also foreign aid flows are generally procyclical, implying that downturns in the richer countries tend to reduce the supply of private and public capital flows (Headey et al. 2009). Subsequently, countries receiving foreign aid cannot expect that current levels of aid (low as they are) can be maintained as donor nations themselves go through the crisis. It has to be mentioned that most of the countries in the region have not received measurable foreign aid in the traditional sense, neither before nor after the crisis. Assistance is provided by the International Monetary Fund (IMF), the World Bank and EU mainly in the form of loans to ensure some sense of stability.

\section{Conclusions}

The crisis that began in the US sub-prime mortgage market and evolved into a world-wide financial and economic crisis has hit the ECA region the hardest. The cumulative impact of job losses and lower real wage rates in combination with the severe drop in remittances of labour migrants, tightened conditions in the agricultural credit market, and reductions in the

\footnotetext{
${ }^{19}$ For instance the general government balance, as percentage of GDP deteriorated in Slovenia from -0.3 (2008) to -5.9 (2009).
} 
social safety programs - to name a few reasons - all contributed to the fall in GDP growth in the region. Growth has plummeted from a fast clip of $7.6 \%$ in 2007 to $4.7 \%$ in 2008, and is projected at negative 5.6\% in 2009 (Schrader - Celasin 2009). This economic development exacerbated the smoldering fiscal crisis. Combined with the tougher international financial market climate, this led to an unsustainable budget deficit. Consequently, the ECA governments hat limited possibilities to intervene in the economy similar to Western European countries - for instance with packages to reflate the marketor with special social programs. Thus, the ECA countries are projected to face a slow economic recovery (World Bank 2010).

When talking about ECA, we do not talk about a uniform region. At least five sub-regions need to be distinguished: (1) the new EU member countries, (2) Russia, (3) the rest of the CIS including the poor Caucasian countries and Moldova, (4) the Central Asian countries, and (5) the West Balkan. The crisis affects the whole region but the way it is handled is not uniform but rather has its own features in the mentioned sub-regions. EU member countries are clearly in the best position to handle the effects of the crisis. The crisis made the advantages of being inside the EU very visible. In this country group, the IMF provided significant financial assistance but not to the extent needed. Oil exporters such as Russia or Kazakhstan had more room for manoeuvre and could support a more expansive fiscal stance. The countries in the other sub-regions suffered most. Countries with a large domestic market, however, could adjust more easily. The negative effects of the crisis were sometimes softened due to the decline of energy prices and the currency depreciation in some countries. As far as the agricultural sector is concerned, there are a few interconnected crises:

- $\quad$ reduction in income elastic food demand and commodity price decline,

- loss of employment and earnings of rural people working in urban centres, implying also costly labour reallocation,

- $\quad$ rising rural poverty originating mainly from lack of opportunities in the non-farm sector and a sizable decline of international remittances,

- $\quad$ tightening of agricultural credit market, and the

- collapse of sectoral government support programs and social safety-net measures in many countries. 
Nevertheless, the crisis hit the farming and the broader agri-business differently in general and in the ECA sub-regions. Large farms or even agroholdings are affected in a similar way as the industrial sector. The effects on the subsistence farms may not be as pronounced and are especially not as visible. The locally owned food processing industry suffered more than large farms due to the tightening of agricultural credit. With the exceptions mentioned here, subsidised credit lines for farming and agro-processing have disappeared almost fully. Only richer countries such as Russia or EU member countries could counteract.

Rural poverty has increased but this was mainly due to spill-over effects from the urban sector and from job losses of rural people in the non-farm sector. Subsistence farmers are still producing mainly for own consumption but there are more of them now. The rural space, especially the farming sector acted as a kind of social buffer as it had done in earlier crises. Nevertheless, the social dimension of the crisis is immense as social safety-net measures were cut down due to the apparent and widening budget deficit in most of the countries. In this context, rural minority groups such as the Roma were affected especially hard. Over $80 \%$ of the Roma in the ECA region are unemployed and mainly live in rural areas. The scarce means to support them have become even more limited due to the fiscal crisis.

Nevertheless, social assistance and unemployment benefits in ECA will be critical in providing a crisis response mechanism to mitigate the adverse impact of the income shocks. Several countries in ECA do have social safety net programs in place to mitigate the income shocks. Nevertheless, as the public budget is further stressed by drowning tax revenues, there is not only a lack of measures to stimulate the economy, but social protection programs may be cut back too.

Key public investments, such as infrastructure development offer opportunities for augmenting employment in the short term, while providing a foundation for future productivity growth. Easing access to finance for small and medium enterprises in the nonfarm sector and farms with growth potential could also help create opportunities for growth and employment. Supporting re-training programs of laid-off workers will help to prepare for the changed labour market after the crisis.

In the face of the unprecedented crisis, governments in ECA countries will have many hard choices to make, given that government deficits will increase from $1.5 \%$ of GDP in 2008 to 
$5.5 \%$ in 2009 . These deficits limit government capacity to adequately finance social safetynets and the required counter-cyclical spending at the same time.

\section{References}

Blanchard, O. J. (2009): The Crisis: Basic Mechanisms, and Appropriate Policies. MIT Department of Economics Working Paper No. 09-01

Bresciani, F. - Geder, G. - Gilligan, D. - Jacoby, H. - Onchan, T. - Quizon, J. (2002):

Weathering the Storm: The Impact of the East Asian Crisis on Farm Households in Indonesia and Thailand. The World Bank Research Observer 17(1): 1-20.

Cecchetti, S. (2009): Rescue, recovery, reform.

http://www.voxeu.org/index.php?q=node73778 (accessed September 2009).

Csáki, C. (2009): Impacts of Transition upon Rural Development and the Rural Population in Central and Eastern Europe. Keynote speech at the IAMO Forum 2009 on "20 Years of Transition in Agriculture”, June 17-19, 2009. Halle

EC (2006): Enlargement, two years after: An economic evaluation. Brussels: European Commission

EC (2009): Economic crisis in Europe: Causes, consequences and responses. Brussels: European Commission

Elliott, L. (2009): World Bank asks rich nations to stump up extra funding. http://www.guardian.co.uk/business/2009/oct/02/ (accessed October 2009).

Ersado, L. - Umali-Deininger, D. (2009): The global economic crisis: Implications for rural Poverty in Europe and Central Asia. Paper at the $27^{\text {th }}$ International Conference of Agricultural Economists (IAAE), 16-22 August 2009, Beijing, China.

Eurostat (2009): Provision of deficit and debt data for 2008 - Second notification. Eurostat News release 149/2009

Freund, C. (2009): Demystifying the collapse in trade. www.voxeu.org/index,php? $\mathrm{q}=$ node/373 (accessed October 2009).

Headey, D. - Malaiyandi, S. - Fan, S. (2009): Navigating the perfect storm: Reflections on the food, energy, and financial crises. Invited panel paper at the $27^{\text {th }}$ International Conference of Agricultural Economists (IAAE), 16-22 August 2009, Beijing, China.

Huang, J. - Rozelle, S. - Zhi, H. - Huang, Z. (2009): Impact of financial crisis on rural labor employment and income in China. Paper at the $27^{\text {th }}$ International Conference of Agricultural Economists (IAAE), 16-22 August 2009, Beijing, China. 
IMF (2009): Global financial stability report. Navigating the financial challenges ahead.

Washington DC: International Monetary Fund

Ivanic, M. - Martin, W. (2008): Implications of higher global food prices for poverty in lowincome countries. Agricultural Economics 39: 405-416.

Kindleberger, C. P. (1937): International short-term capital movements. New York: Augustus Kelley.

Korolev, I. (2009): Global financial crisis: Impact upon Russia. Moscow: Institute of World Economy and International Relations

Lin, J.Y., - Martin, W. (2009): The Financial Crisis and Its Impact on the Global Agricultural Landscape. Invited Paper at the $27^{\text {th }}$ International Conference of Agricultural Economists (IAAE), 16-22 August 2009, Beijing, China

McKibbin, W. - Stoeckel, A. (2009): The effects of the global financial crisis on world trade. Washington DC: World Bank.

McKibbin, W. - Martin, W. (1999): The East Asian crisis: Investigating causes and policy responses. World Bank Policy Research Working Paper 2172.

Montes-Negret, F. (2009): The 2008-09 financial crisis: USA - Europe, synchronized but different. Taranto Finanza Forum, http:/www.tarantofinanzaforum.com/pdf/ comunicati/090929_tff.pdf (accessed October 2009).

OECD (2009): Agricultural policies in OECD countries. Monitoring and evaluation. Paris: Organization for Economic Cooperation and Development

Orlowski, L. (2009): Die Phasen der weltweiten Finanzkrise: Gibt es eine 'wandernde' speculative Blase? Wirtschaft im Wandel (März): 20-25.

Ratha, D. - Mohapatra, S. - Silwal, A. (2009): Outlook for remittance Flows 2009-2011: Remittances expected to fall by $7-10 \%$ in 2009. Migration and Remittance Brief 10 . Washington DC: World Bank

Sandschneider, E. (2008): Russian ambitions in the energy sphere and the global financial crisis. DGAP aktuell 7. Berlin: Deutsche Gesellschaft für Auswärtige Politik.

Schmognerova. B. (2005): Under-secretary-general and executive secretary of the Economic Commission for Europe (ECE). New York: United Nations, http://www.un.org/esa/socdev /csd/2005/Statements/ece.pdf (accessed October 2009).

Schneider, B. (2003): Measuring capital flight: Estimates and interpretations. Working Paper 194. London: Overseas Development Institute

Schrader, K. - Celasin, T. (2009): Global Crisis Hits Home in Emerging Europe and Central Asia, http://web.worldbank.org/WBSITE 
/EXTERNAL/NEWS/0,,contentMDK:22338267 pagePK:64257043 piPK:437376 the SitePK:4607,00.html (accessed October 2009)

World Bank (2000): Rural development strategy Eastern Europe and Central Asia. World Bank Technical Paper No. 484.

World Bank (2009): The crisis hits home: Stress testing households in Europe and Central Asia, http://siteresources.worldbank.org/NEWS/Resources/ECAEconUpdateOct3.ppt (accessed October 2009).

World Bank (2010): Turmoil at twenty - recession, recovery, and reform in Central and Eastern Europe and the Former Soviet Union. Washington DC: World Bank. 